Brit. F. industr. Med., 1966, 23, 305

\title{
Chronic Toxicity of Aluminium in Rats and Mice and its Effects on Phosphorus Metabolism
}

\author{
R. ONDREIČKA, E. GINTER, and J. KORTUS \\ From the Institute of Human Nutrition Research, Bratislava, Czechoslovakia
}

In mice the oral $\mathrm{LD}_{50}$ values of aluminium chloride and aluminium sulphate were $0.77 \pm 0.12$ and $0.98 \pm 0.09$ g. Al $/ \mathrm{kg}$. ( \pm S.E.) respectively.

Mice and rats were fed on a normal diet containing about I70 p.p.m. of aluminium. Doubling this concentration caused a decrease in growth in the second and third generations of mice. A high intake of aluminium sulphate (2,835 p.p.m.) caused a 20-fold increase of aluminium retention in white rats. Aluminium accumulated in various tissues, especially in the skeleton, liver, and testes. A high rate of intake $(2,665$ p.p.m.) caused a negative phosphorus balance in the rat, with an increased output of phosphorus in the faeces. The lower absorption of phosphorus was also demonstrated with $\mathrm{Na}_{2} \mathrm{H}^{32} \mathrm{PO}_{4}$. Chronic and acute poisoning by aluminium chloride caused, after intraperitoneal $\mathrm{Na}_{2} \mathrm{H}^{32} \mathrm{PO}_{4}$, decreased incorporation of ${ }^{32} \mathrm{P}$ into the phospholipids and nucleic acids of various tissues in the rat. It also caused a fall in the adenosinetriphosphate acid-levels in plasma, and a rise in the adenosine diphosphate level.

The results suggest that the toxic effects of aluminium salts result both from decreased absorption of phosphorus and from interference with phosphorylation processes in the tissues.

Modern applied research into possible applications of aluminium has resulted in the introduction of many inorganic and organic compounds of the most diverse and common use. There is, however, no general consensus of opinion on the toxicity of aluminium salts. On the one hand it has been stated: 'aluminium compounds are harmless when ingested, even when the administration is continued over long periods' (Quarterly Bulletin of the Association of Food and Drug Officials of the United States, 1955); on the other hand, there is evidence that various toxic effects are induced in experimental animals by the administration of large amounts of aluminium compounds (Seibert and Wells, 1929; Stenberg and Naumova, 1952; Vojnar, 1953; Hara, Seki, Usui, Nakakawaji, and Mori, 1959a).

The original conclusion that aluminium given by mouth was wholly excreted has been proved to be wrong. More recent papers agree that various aluminium compounds given in large doses are partly absorbed and transported into the tissues (Perry, Tipton, Schroeder, and Cook, 1962; Kortus, Dibák, and Kotuliak, 1963). The toxicity of aluminium salts in the diet has been studied only at very high doses. Not even with doses as large as 2,000 parts $\mathrm{Al}$ per million have pathological changes

Received for publication December 29, 1965. in individual organs been observed. The only effect is growth retardation (Hara et al., 1959b). Similar results have been obtained by Vozár (1959).

Aluminium in the diet has been shown to interact with phosphate in the alimentary tract and to affect its metabolism (Ivy and Gray, 1939; Jones, 1942).

The aims of this work were to study the effects of moderately low doses of aluminium on the growth of animals in succeeding generations, and to compare the effects of chronic low and acute high doses of aluminium on the retention and fate of aluminium and on the retention and fate of phosphorus with special reference to phosphorus compounds of fundamental metabolic importance.

\section{Materials and Methods}

Animals Rats were of the Wistar strain, weighing 150 to $250 \mathrm{~g}$. Mice were of the 'Dobrá Voda' strain from the Slovakian Academy of Science, Dobrá Voda, average weight $200 \mathrm{~g}$. Male animals were used for all but experiments on succeeding generations, in which a male/female ratio of 0.4 was maintained. Animals were fed on the Larsen diet (Fábry, 1955). This normal diet contained 160 to 180 parts per million (p.p.m.) of aluminium and about 6,000 p.p.m. of phosphorus.

Aluminium All doses are expressed in terms of aluminium. The chloride was mostly used, but the sulphate was used in some experiments. 
Acute Toxicity Studies The aluminium salt was given orally by probe.

Chronic Toxicity Studies The aluminium salt was given in the drinking water or admixed in the diet. Weights of animals and daily food and water intake were checked at intervals.

Balance Studies Animals were kept in metabolic cages allowing separate collection of urine and faeces for $24 \mathrm{hrs}$. during which no food was given. They were then decapitated. Aluminium in the urine, faeces, and tissues was estimated by Nikitina's (1956) procedure, and phosphorus by Travina's (1955) method.

In tracer studies rats were given by mouth $\mathrm{Na}_{2} \mathrm{H}^{32} \mathrm{PO}_{4}$ (IO mg. $/ \mathrm{ml}$. in $0.9 \% \mathrm{NaCl}$ ) obtained from the Institute of Nuclear Research, Rež, Czechoslovakia at the beginning of the period. ${ }^{32} \mathrm{P}$ was either estimated after digestion of the tissues with perchloric acid or in tissue fractions: acid soluble; phospholipid; ribonucleic and deoxyribonucleic acids. These were separated as described by Davidson, Frazer, and Hutchison (I95I). ${ }^{32} \mathrm{P}$ estimations were carried out by end-window counting on aluminium discs using a Geiger-Müller tube.

Adenosine mono-, di-, and tri-phosphates in the blood serum of rats were estimated by Boehringer's enzymic methods (Bücher, 1953).

\section{Results}

Oral LD 50 Values of Aluminium in Mice As aluminium chloride was used in most chronic toxicity experiments its acute $\mathrm{LD}_{50}$ value was determined and compared with that of the sulphate. After approximate $\mathbf{L D}_{50}$ values had been found, more precise values were determined by Roth's nomographic procedure (I96I). The $\mathrm{LD}_{50}$ value of the chloride was found to be $0.77 \pm 0.12 \mathrm{~g}$. Al/kg., and of the sulphate $0.98 \pm 0.09 \mathrm{~g}$. Al $/ \mathrm{kg}$. (means \pm S.E.). These values are not significantly different. They place aluminium salts in the category of compounds with low acute toxicities according to the criteria of Hodge and Sterner, as quoted by Simonnet (1956).

Chronic Toxicities in Mice The chronic toxicity was studied in a reproduction experiment on white mice. Ten mice received aluminium chloride in their drinking water, receiving on the average $19.3 \mathrm{mg}$. Al/kg./day. They were compared with ro control mice. The experiment lasted 180 to 390 days, during which weight increases, number of litters, and number of off-spring were recorded.

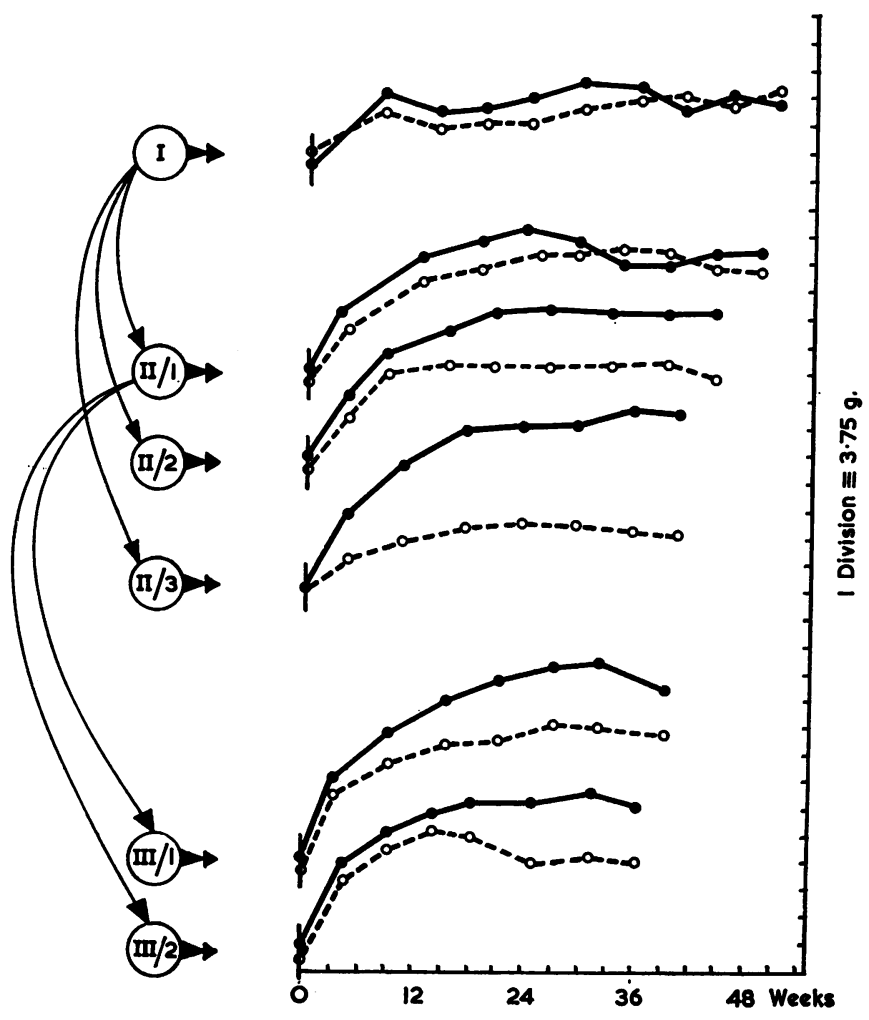

FIG. I. Weight increases of normal (full lines) and of aluminium trichloride treated (dotted lines) white mice: $I$, original generation; II / I, 2, 3, first, second, and third litter of the second generation; III $/ 1,2$, first and second litter of the third generation. 
The weanlings were treated from 4 weeks of age like their parents. At the end of the experiment the animals were killed by decapitation, the blood was examined for changes in the red cell count, and the liver, spleen, and kidneys were examined histologically.

There were no significant differences in the numbers of litters or off-spring between the treated and control mice. Growth was retarded and was dependent on the intake of aluminium, but the effect did not appear in the first generation or in the first litter. The subsequent litters manifested a very marked growth retardation, as did those of the third generation (Fig. I). An analysis of variance (Weber, 1964) established that, under the conditions of our experiment, weight variations could be accounted for by aluminium uptake $(P<0.001)$. The differences in the course of weight plots for successive generations and litters were also statistically significant $(P<0.01)$.

The erythrocyte counts and haemoglobin levels in the first and last generations did not differ significantly from those in the controls; and no pathological changes could be found in the tissues examined.
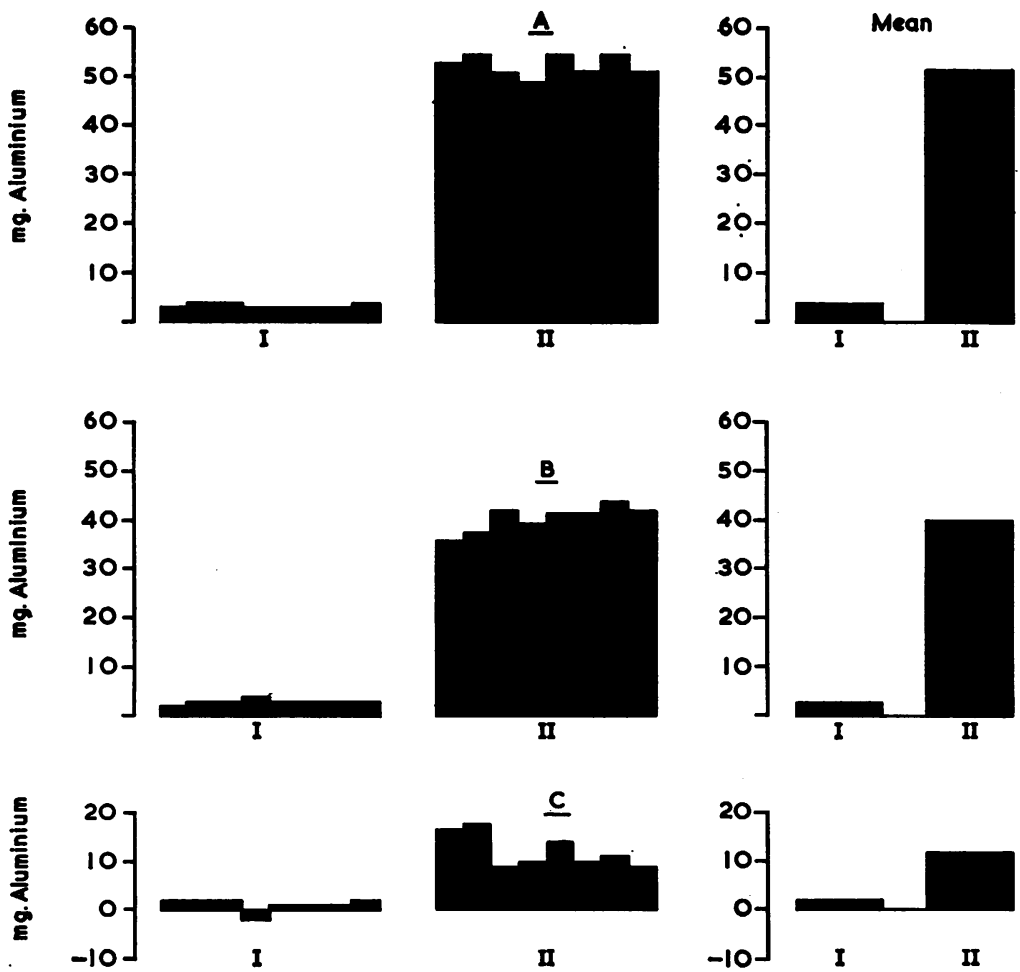

TABLE I

Aluminium Balance in Mice kePt on Diets with DIFFERENT ALUMINIUM CONTENTS

\begin{tabular}{|c|c|c|}
\hline \multicolumn{2}{|l|}{ Aluminium (mg.) } & \multirow{2}{*}{$\begin{array}{l}\text { Statistical } \\
\text { Significance }\end{array}$} \\
\hline $\begin{array}{l}\text { Control } \\
\text { (I70 p.p.m. Al) }\end{array}$ & $\begin{array}{l}A l C l_{3} \\
(355 \text { p.p.m. Al })\end{array}$ & \\
\hline $3.87 \pm$ & $7 \cdot 75 \pm 1 \cdot 00$ & $P<0.01$ \\
\hline $\begin{array}{r}2.47 \pm 0.19 \\
0.11 \pm 0.03 \\
-1.28 \pm 0.38\end{array}$ & $\begin{array}{r}5.72 \pm 0.71 \\
0.11 \pm 0.04 \\
+1.91 \pm 0.51\end{array}$ & $\begin{array}{l}\mathbf{P}<0.002 \\
\mathbf{P}>0.05 \\
\mathbf{P}>0.05\end{array}$ \\
\hline
\end{tabular}

The average values \pm S.E. for 10 mice over 24 hours are given.

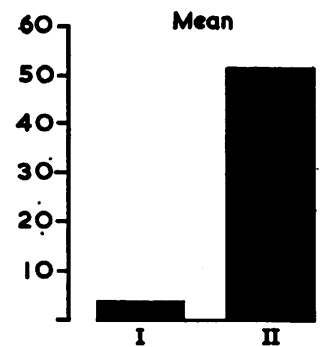

FIG. 2. Influence of high doses of aluminium sulphate on the aluminium balance in rats: $A$, aluminium intake; $B$, aluminium excretion; $C$, aluminium retention; I, control group (I70 p.p.m. Al in diet); II, treated group (2,835 p.p.m. Al in diet). All values are expressed in $\mathrm{mg}$. Al. 
nificantly higher at the higher dose, whereas urinary excretion and the retention of aluminium were not.

The aluminium balance was also studied in eight rats kept for eight days on the diet containing 160 to I80 p.p.m. Al and then given a diet containing 2,835 p.p.m. Al (as sulphate) for a further eight days. The increased dose rate of aluminium led to a reduction in food intake from 20 to $15 \mathrm{~g}$./rat/day and a reduction in average body weight. Aluminium excretion was increased significantly in both faeces and urine $(P<0.001)$ when the higher dose was given (Fig. 2). About $70 \%$ of the dose was excreted in the faeces. Retention was increased 20 times.

Increased retention in several tissues from a higher dose was also demonstrated in two groups of eight rats each by analysis of the tissues (Table II).

\section{TABLE II}

INFLUENCE of Dose Rates on Aluminium Levels in RAt Tissues

\begin{tabular}{|c|c|c|c|}
\hline \multirow[b]{2}{*}{ Tissue } & \multicolumn{2}{|c|}{ Concentration of Al in Diet } & \multirow{2}{*}{$\begin{array}{l}\text { Statistical } \\
\text { Significance }\end{array}$} \\
\hline & $I 70$ p.p.m. & 2,835 p.p.m. & \\
\hline Liver & $1.55 \pm 0.26$ & $2.99 \pm 0.28$ & $\mathbf{P}<0.001$ \\
\hline Brain & $0.71 \pm 0.08$ & $1.08 \pm 0.15$ & $\mathbf{P}<0.05$ \\
\hline Kidneys & $0.86 \pm 0.08$ & $0.90 \pm 0.10$ & $P>0.05$ \\
\hline Adrenals & $41 \cdot 5 \pm 5 \cdot 2$ & $51 \cdot 4 \pm 5.5$ & $P>0.05$ \\
\hline Spleen & $I .46 \pm 0.23$ & $1 \cdot 48 \pm 0.10$ & $P>0.05$ \\
\hline Heart & $1.08 \pm 0.12$ & $1.27 \pm 0.12$ & $P>0.05$ \\
\hline Lungs & $0.407 \pm 0.054$ & $0.428 \pm 0.080$ & $P>0.05$ \\
\hline Testes & $0.170 \pm 0.057$ & $0.470 \pm 0.060$ & $\mathbf{P}<0.001$ \\
\hline Colon & $0.69 \pm 0.10$ & $0.63 \pm 0.04$ & $P>0.05$ \\
\hline Muscle & $0.039 \pm 0.008$ & $0.044 \pm 0.002$ & $P>0.05$ \\
\hline Blood & $0.65 \pm 0.11$ & $1.08 \pm 0.09$ & $P<0.01$ \\
\hline Femur & $\pm \mathbf{r} \cdot \mathbf{0}$ & \pm 0.7 & $\mathrm{P}<0.00 \mathrm{I}$ \\
\hline
\end{tabular}

Aluminium concentrations are given in mg./100 g. fresh tissue. The diet was maintained for 24 days before the rats were killed.

One group received the basic diet containing 160 to I80 p.p.m., the other a diet containing 2,835 p.p.m., both for 24 days.

Influence of Aluminium on Metabolism of Phosphorus Ten mice received the standard diet containing 160 to 180 p.p.m., and Io a diet containing 355 p.p.m. for 40 days, and the phosphorus balance was studied during the last six days. The higher dose significantly lowered phosphorus retention (Table III), which, on some days, even became negative, i.e., there was net excretion. The concentrations of phosphorus in the liver and femur were not, however, significantly affected by the end of the experiment. The weight plots were also unaffected in spite of some reduction in food intake in animals fed the diet containing increased amounts of aluminium.
TABLE III

Phosphorus Balance in Mice kept for 40 Days on Diets CONTAININg Different Aluminium LeVels

\begin{tabular}{lll}
$\begin{array}{l}\text { Phosphorus (mg.) } \\
\begin{array}{l}\text { Control } \\
\text { (I70 p.p.m. Al) }\end{array}\end{array}$ & $\begin{array}{l}\text { AlCl } \\
\text { (355 p.p.m. } A l)\end{array}$ & \\
\hline $218.8 \pm 10.3$ & $148.1 \pm 20.4$ & P $<0.02$ \\
& & \\
$150.4 \pm 5.4$ & $139.5 \pm 28.6$ & P $>0.05$ \\
$2.9 \pm 0.6$ & $3.7 \pm 0.8$ & P $>0.05$ \\
$+65.6 \pm 13.0$ & $+4.9 \pm 14.4$ & P $<0.02$
\end{tabular}

The average values \pm S.E. for 10 mice over 24 hours are given.

More pronounced changes in the phosphorus balance were found in eight rats kept for eight days on the standard diet and for another eight days on the same diet containing an additional 2,665 p.p.m. $\mathrm{Al}$ as sulphate. The addition of the aluminium salt to the diet resulted in a lower food intake and consequently to a significantly lower phosphorus intake $(\mathbf{P}<0.00 \mathrm{r})$ and a reduced excretion of phosphorus in the urine $(P<0.001)$. The excretion of phosphorus in faeces was, however, increased $(P<$ 0.001 ). These effects are illustrated in Figure 3.

In the first series of tracer experiments, the influence was studied of a single large oral dose of aluminium chloride, $188.2 \mathrm{mg}$. $/ \mathrm{kg}$. body weight, on the absorption of $\mathrm{Na}_{2} \mathrm{H}^{32} \mathrm{PO}_{4}, 0 \cdot \mathrm{I} \mu \mathrm{c} / \mathrm{IOO} \mathrm{g}$. wt., given orally 15 minutes after the aluminium salt. The experimental and control groups were each of eight rats. The distribution of radioactivity in the urine, faeces, blood, and various tissues was measured. The results are summarized in Table IV.

\section{TABLE IV}

INFLUENCE OF ALUMINIUM TRICHLORIDE INTOXICATION ON THE TISSUE INCORPORATION AND EXCRETION OF ${ }^{32} \mathrm{P}$ IN RATS

\begin{tabular}{lccc} 
Sample $\begin{array}{l}\text { Control } \\
\text { (cts./min.) }\end{array}$ & $\begin{array}{l}\text { Single Oral Dose } \\
\text { of } 188 \mathrm{mg} . / \mathrm{kg} . \\
\text { (cts./min.) }\end{array}$ & $\begin{array}{l}\text { Statistical } \\
\text { Signi- } \\
\text { ficance }\end{array}$ \\
\hline Blood & $982 \pm 73$ & $77 \pm 1 \mathrm{I}$ & $\mathrm{P}<0.001$ \\
Liver & $6,891 \pm 936$ & $342 \pm 52$ & $\mathrm{P}<0.001$ \\
Spleen & $3,934 \pm 306$ & $140 \pm 29$ & $\mathrm{P}<0.001$ \\
Kidneys & $4,644 \pm 489$ & $327 \pm 69$ & $\mathrm{P}<0.001$ \\
Brain & $816 \pm 75$ & $190 \pm 61$ & $\mathrm{P}<0.001$ \\
Muscle & $1,986 \pm 165$ & $33 \pm 10$ & $\mathrm{P}<0.001$ \\
Femur & $23,390 \pm 2,040$ & $950 \pm 280$ & $\mathrm{P}<0.001$ \\
Faeces/ & & & \\
24 hours I,799,000 $\pm 378,000$ & $1,974,000 \pm 565,000$ & $\mathrm{P}>0.05$ \\
Urine/ & & & \\
24 hours I, 195,000 $\pm 197,000$ & $20,750 \pm 4,190$ & $\mathrm{P}<0.001$
\end{tabular}

Average values \pm S.E. are given.

For blood the count rates are per $100 \mu \mathrm{l}$., for tissues per $100 \mathrm{mg}$., and for faeces and urine the total excreted in 24 hours.

See text for further details. 

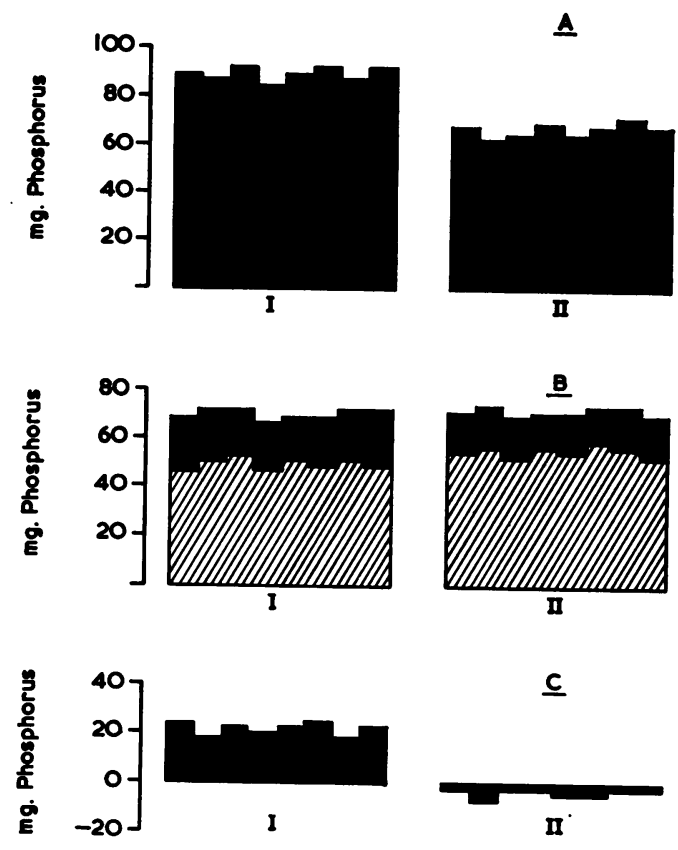
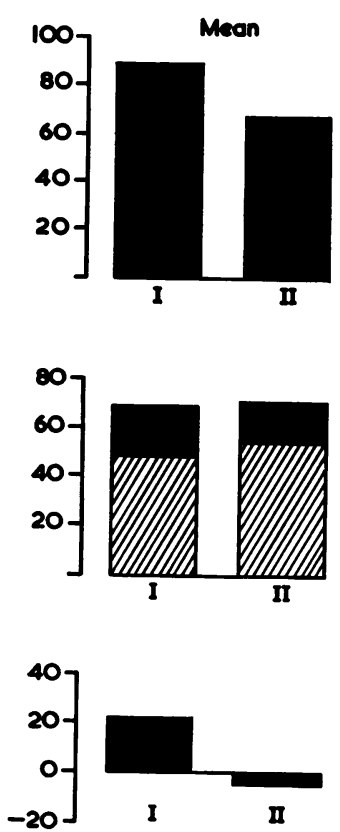

FIG. 3. Influence of high doses of aluminium sulphate on the phosphorus balance in rats: A, phosphorus intake; $B$, phosphorus excretion (lined area-faecal excretion); C, phosphorus retention. I, control group; II, treated group. All values are expressed in mg. phosphorus.
They show a significant reduction of ${ }^{32} \mathrm{P}$ incorporation into the blood and all the tissues examined. The increase in the excretion of ${ }^{32} \mathrm{P}$ in the faeces is not significant and is less than one expects if there is formation of complexes of aluminium and phosphate anions which are absorbed with difficulty. This finding is obviously influenced by the lower total excretion of faeces during our experiment, since after the administration of large amounts of aluminium chloride constipation occurs. The low level of ${ }^{32} \mathrm{P}$ in the blood, in tissues, and in urine, however, clearly shows reduced phosphorus absorption. Owing to technical difficulties the contents of the digestive tract were not analysed. This omission explains the failure to achieve 100\% recoveries of injected ${ }^{32} \mathrm{P}$.

In the second series of tracer experiments the influence of chronic and acute intoxication by aluminium chloride on the metabolism of ${ }^{32} \mathrm{P}$ was studied. The ${ }^{32} \mathbf{P}$ was injected intraperitoneally at $0.16 \mu \mathrm{C} / \mathrm{r} 00 \mathrm{~g}$. to ensure complete absorption. The experiment was carried out with rats, divided into three groups of six animals. One of the groups served as a control, the second group was given daily oral doses of aluminium chloride $(36.5 \mathrm{mg}$. $\mathbf{A l} / \mathbf{k g}$.) for a period of 52 days, and the third group received, after having been fed the standard diet for 52 days, a single large intragastric dose of aluminium chloride of $240 \mathrm{mg}$. Al/ $\mathrm{kg}$. Administration of aluminium did not influence food intake or the weight curves of the animals. The average body weight of the animals of the control group at the end of the experiment was $206 \mathrm{~g}$. and that of the group with chronic aluminium intake was $22 \mathrm{I} \mathrm{g}$. $\mathrm{Na}_{2} \mathrm{H}^{32} \mathrm{PO}_{4}$ was given (to the last group at the same time as the aluminium) and $24 \mathrm{hrs}$. later the specific activities of phosphorus fractions isolated from the liver, spleen, and kidney tissues were measured. The results obtained (Table V) prove that, whereas the specific activity of acid soluble phosphorus was not influenced by either chronic or acute intoxication, the incorporation of ${ }^{32} \mathrm{P}$ into phospholipids and ribonucleic and deoxyribonucleic acid fractions was in most cases significantly reduced. The effect of acute intoxication was, as a rule, more pronounced.

In another similar experiment the influence was studied of chronic and acute intoxications by aluminium chloride on the blood serum level of adenosine mono-, di-, and tri-phosphates in 30 rats divided into three groups. All rats were fed the standard diet for 55 days. The first experimental group received additional aluminium chloride throughout the 55 days at $36.5 \mathrm{mg}$. Al $/ \mathrm{kg}$./day. This did not affect the average final body weight significantly (215 g. for controls; $209 \mathrm{~g}$. for the treated rats). The second experimental group received one oral dose of $223 \mathrm{mg}$. Al/kg. (as the chloride) on the fifty-sixth day. The results are shown in Table VI. They indicate that aluminium chloride treatment causes an increase of adenosine mono- and di- 
TABLE V

Influence of Chronic and Acute Aluminium Trichloride Intoxication on the Incorporation of ${ }^{32} \mathrm{P}$ into Tissue Fractions In THE Liver, SPLEEN, AND KidNEYS OF RATS

\begin{tabular}{|c|c|c|c|c|c|}
\hline \multirow[t]{2}{*}{ Fraction } & \multicolumn{3}{|c|}{ Specific Activity (counts/min./roo $\mu g . P$ ) } & \multicolumn{2}{|c|}{ Significance against Control } \\
\hline & Control & $\begin{array}{l}\text { Chronic } \\
\text { Intoxication }\end{array}$ & $\begin{array}{l}\text { Acute } \\
\text { Intoxication }\end{array}$ & $\begin{array}{l}\text { Chronic } \\
\text { Intoxication }\end{array}$ & $\begin{array}{l}\text { Acute } \\
\text { Intoxication }\end{array}$ \\
\hline \multicolumn{6}{|l|}{ Liver } \\
\hline $\begin{array}{l}\text { Acid-soluble P } \\
\text { Lipid P } \\
\text { RNA } \\
\text { DNA }\end{array}$ & $\begin{array}{l}1,944 \pm 96 \\
2,139 \pm 108 \\
1,234 \pm 65 \\
176 \pm 16\end{array}$ & $\begin{array}{l}1,806 \pm 81 \\
1,720 \pm 132 \\
928 \pm 40 \\
172 \pm 23\end{array}$ & $\begin{array}{c}2,244 \pm 132 \\
1,625 \pm 61 \\
870 \pm 207 \\
95 \pm 15\end{array}$ & $\begin{array}{l}P>0.05 \\
P<0.05 \\
P<0.01 \\
P>0.05\end{array}$ & $\begin{array}{l}P>0.05 \\
P<0.01 \\
P>0.05 \\
P<0.01\end{array}$ \\
\hline \multicolumn{6}{|l|}{ Spleen } \\
\hline $\begin{array}{l}\text { Acid-soluble D } \\
\text { Lipid P } \\
\text { RNA } \\
\text { DNA }\end{array}$ & $\begin{array}{l}2,395 \pm 177 \\
1,294 \pm 176 \\
1,671 \pm 504 \\
2,285 \pm 1,324\end{array}$ & $\begin{aligned} & 1,997 \pm 112 \\
& 986 \pm 55 \\
& 1,242 \pm 119 \\
& 1,750 \pm 227\end{aligned}$ & $\begin{array}{r}1,736 \pm 356 \\
744 \pm 271 \\
358 \pm 131 \\
252 \pm 62\end{array}$ & $\begin{array}{l}P>0.05 \\
P>0.05 \\
P>0.05 \\
P>0.05\end{array}$ & $\begin{array}{l}P>0.05 \\
P>0.05 \\
P<0.01 \\
P<0.01\end{array}$ \\
\hline \multicolumn{6}{|l|}{ Kidneys } \\
\hline $\begin{array}{l}\text { Acid-soluble P } \\
\text { Lipid P } \\
\text { RNA } \\
\text { DNA }\end{array}$ & $\begin{array}{l}1,994 \pm 57 \\
1,743 \pm 194 \\
834 \pm 65 \\
128 \pm \mathbf{2 8}\end{array}$ & $\begin{array}{c}1,801 \pm 83 \\
1,190 \pm 77 \\
696 \pm 57 \\
334 \pm 152\end{array}$ & $\begin{array}{c}2,238 \pm 95 \\
1,013 \pm 61 \\
602 \pm 69 \\
44 \pm 8\end{array}$ & $\begin{array}{l}P>0.05 \\
P<0.05 \\
P>0.05 \\
P>0.05\end{array}$ & $\begin{array}{l}P>0.05 \\
P<0.05 \\
P<0.05 \\
P<0.05\end{array}$ \\
\hline
\end{tabular}

Average values \pm S.E. are given. See text for details.

TABLE VI

Influence of Chronic and Acute Intoxication by Aluminium Chloride on the Level of Adenosine Mono-, Di- and Triphosphates IN RAT BLOOD

\begin{tabular}{|c|c|c|c|c|c|}
\hline \multirow[t]{2}{*}{ Acid } & \multirow[t]{2}{*}{ Control } & \multirow{2}{*}{$\begin{array}{l}\text { Chronic } \\
\text { Intoxication }\end{array}$} & \multirow{2}{*}{$\begin{array}{l}\text { Acute } \\
\text { Intoxication }\end{array}$} & \multicolumn{2}{|c|}{ Significance against Control } \\
\hline & & & & $\begin{array}{l}\text { Chronic } \\
\text { Intoxication }\end{array}$ & $\begin{array}{l}\text { Acute } \\
\text { Intoxication }\end{array}$ \\
\hline $\begin{array}{l}\text { AMP (mg./100 ml.) } \\
\text { ADP (mg./100 ml.) } \\
\text { ATP (mg./100 ml.) }\end{array}$ & $\begin{array}{l}2.95 \pm 0.19 \\
3.69 \pm 0.19 \\
8.33 \pm 0.41\end{array}$ & $\begin{array}{l}3 \cdot 18 \pm 0.60 \\
4.50 \pm 0.42 \\
7.56 \pm 0.95\end{array}$ & $\begin{array}{l}3.48 \pm 0.27 \\
4.39 \pm 0.11 \\
5.52 \pm 0.44\end{array}$ & $\begin{array}{l}\mathbf{P}>0.05 \\
\mathbf{P}>0.05 \\
\mathbf{P}>0.05\end{array}$ & $\begin{array}{l}\mathbf{P}>0.05 \\
\mathbf{P}<0.01 \\
\mathbf{P}<0.001\end{array}$ \\
\hline
\end{tabular}

Average values \pm S.E. are given. See text for other details.

phosphates, and a decrease of adenosine triphosphate. The effects of acute intoxication were more pronounced and are statistically significant.

\section{Discussion}

In the introduction to this paper the conflict of opinions regarding the toxicity of aluminium compounds was emphasized. Our own studies resulted in our classifying aluminium chloride and sulphate as compounds of low acute toxicity. This conclusion was based on oral $\mathrm{LD}_{50}$ values. The intravenous toxicity of aluminium salts is much higher (Hara et al., 1959a) but is of little relevance as this is not a possible path of aluminium intake in everyday life.

The effects of the chronic intake of only slightly increased amounts of aluminium seem to be considerably more significant. They have been little studied in the past. In the present experiments the effects of low doses of aluminium chloride on the growth rates of three generations of mice were studied. The results show that weight gains were less, but not in the first generation. As retardation of growth was caused by relatively small doses of an aluminium compound, we consider this finding to be important. The results contradict opinions expressed in earlier papers that aluminium exerted no toxic effects at such doses. The lack of significant departures from normal either in the blood count or in the morphology of various tissues of these animals is, however, in accordance with the earlier results of Hara et al. (1959b) and underlines the necessity for seeking other, more sensitive indices of metabolic disturbances caused by a chronic intake of small amounts of aluminium compounds.

In the earlier papers, due to the low sensitivity of the analytical methods used, it was stated that aluminium was not absorbed and should be excreted 
quantitatively in the faeces. More recent papers, however, have indicated that a small fraction of aluminium is absorbed by demonstrating it in all tissues, in blood, and in urine (Kehoe, Cholak, and Storey, I940a, I940b; Heupke, 1950; Campbell, Cass, Cholak, and Kehoe, 1957; Perry et al., 1962; Kortus et al., 1963). We have shown that doubling the aluminium intake caused a significant increase of aluminium output in the faeces but did not significantly influence either its retention or its level in some tissues. On the other hand, a considerable increase in intake by the rat resulted in a large increase in retention and in excretion in the urine. The increased retention of aluminium was also demonstrated by analysis of several tissues. The most pronounced accumulation of aluminium was observed in the liver, testes, and bones, whereas in other organs (kidneys, spleen, lungs, intestines, and muscles) the aluminium levels were not significantly altered. The finding of a very high concentration, Io times greater than in other soft tissues, of aluminium in the adrenals is interesting. Apparently animals can balance moderate increases in the intake of aluminium by a higher output in the faeces; but an extreme increase in the intake of aluminium results in increased absorption, part being deposited in some tissues, mainly in the skeleton and the liver, and part being excreted in the urine.

The mechanisms of the toxic effects of aluminium salts have not yet been elucidated. Several authors (Leary and Sheib, 1917; Jones, 1938; Kirsner, 1943) agree that the primary effects are caused by the reaction of aluminium with phosphates in the gastro-intestinal system, with the formation of insoluble phosphates of aluminium. The simplified reaction may serve as an example:

$$
\begin{aligned}
\mathrm{Na}_{2} \mathrm{HPO}_{4}+\underset{2}{\mathrm{NaH}_{2} \mathrm{PO}_{4}+2 \mathrm{AlCl}_{3} \rightleftharpoons} \rightleftharpoons \\
\underset{2}{\rightleftharpoons}
\end{aligned}
$$

As a consequence of such reactions the output of phosphate in the faeces is increased, thus depriving the animal of phosphorus. Our balance studies, carried out with both rats and mice, have fully confirmed this hypothesis. The standard diet contained about I7O p.p.m. Al. Merely doubling this resulted in a sharp decrease in the positive phosphorus balance in mice. Administration of high doses of aluminium caused a considerable negative balance of phosphorus. The results may have been distorted by a lowered food intake. To render them more convincing, pair feeding experiments would be needed. However, an isotope study, in which ${ }^{32} \mathrm{P}$ incorporation was followed after a single dose of aluminium chloride and in which the nutritional state at the time of the experiment was the same in the experimental and in the control group, demon- strated unequivocally that phosphorus absorption was reduced.

Even when the effects on the absorption of phosphorus were eliminated, by intraperitoneal injection, it was found that feeding high doses of aluminium salts influenced the metabolism of phosphorus. Both chronic and acute dosing led to a decreased incorporation of ${ }^{32} \mathrm{P}$ into the phospholipid fraction and into the ribonucleic and deoxyribonucleic acids in several tissues. The controlling factor was not the supply of ${ }^{32} \mathrm{P}$ to the tissues, as the specific activity of the acid-soluble phosphate fraction was in no case significantly decreased. As the incorporation of phosphate into phospholipids and nucleic acids is determined by the activity of the phosphorylation mechanisms, the results obtained suggest the impairment of this activity by aluminium salts. An important component of the phosphorylation process is adenosine triphosphate; accordingly, we demonstrated a decrease in the adenosine triphosphate levels in the blood serum of rats, and increases in adenosine mono- and di-phosphates, in both chronic and acute intoxication. The significant decrease in the ATP/ADP ratio suggests that the equilibrium of the system:

$$
\begin{aligned}
\mathrm{ATP} \rightleftharpoons \mathrm{ADP}+\text { inorganic } \mathrm{P} \rightleftharpoons \mathrm{AMP} & + \text { inorganic } \mathrm{P}
\end{aligned}
$$

is shifted to the right. We do not know the actual mechanism operating. It may be connected with the decrease in inorganic phosphate in the blood of poisoned animals. Recently such a decrease has been shown by Pragay (1962) in chicken intoxicated by aluminium hydroxide. Our results on ${ }^{32} \mathrm{P}$ incorporation were not influenced by a lowered food intake since the rats of all groups gained weight at very similar rates.

Our results therefore demonstrate that the metabolism of phosphorus compounds is profoundly disturbed by the intake of aluminium salts. Not only is the absorption of phosphorus affected, but so are the phosphorylation mechanisms in the tissues.

\section{REFERENCES}

Bücher, T. (1953). Advances in Enzymology, 14, I. Campbell, I. R., Cass, J. S. Cholak, J., and Kehoe, R. A. (1957). Arch. industr. Hlth, 15, 359.

Davidson, J. N., Frazer, S. C., and Hutchison, W. C. (195I). Biochem. F., 49, 31 I.

Editorial Report (1955). Quart. Bull. Ass. Food Drug Officials U.S., 19, 113.

Fábry, P. (1955). Cs. Fysiol., 4, 33.

Hara, S., Seki, T., Usui, H., Nakakawaji, K., and Mori, G. (1959a). Tokyo Ika Daigaku Zasshi, 17, 1337.

$\longrightarrow,-,-$, and - (1959b). Ibid., 17, 1345.

Heupke, W. (1950). Münch. med. Wschr., 92, 35 I.

Ivy, A. C., and Gray, J. S. (1939). Int. Abstr. Surg., 68, 229. 
Jones, J. H. (1938). Amer. F. Physiol., 124, 230. (1942). F. biol. Chem., 142, 557.

Kehoe, R. A., Cholak, J., and Story, R. V. (I940a). F. Nutr., I9, 579. , and (1940b). Ibid., 20, 85 .

Kirsner, J. B. (1943). F. clin. Invest., 22, 47.

Kortus, J., Dibák, O., and Kotuliak, V. (1963). Cs. Gastroent. Výz., 17, 202.

Leary, J. T., and Sheib, S. H. (1917). F. Amer. chem. Soc., 39, 1066.

Nikitina, E. J. (1956). Semimicrochemical Methods of Analysis of Metals and Alloys. Goschimizdat, Moscow.

Perry, H. M., Tipton, J. H., Schroeder, H. A., and Cook, M. J. (1962). F. Lab. clin. Med., 60, 245.
Pragay, D. A. (1962). Fed. Proc., 21, no. 2, p. 388.

Roth, Z. (196r). Cs. Fysiol., ro, 408.

Seibert, F. B., and Wells, H. G. (1929). Arch. Path., 8, 230.

Simonnet, H. (1956). Aliment. et Vie, 43, 114.

Stenberg, A. J., and Naumova, L. P. (1952). Biul. eksp. Biol. Med., 33, 2, 38.

Travina, O. B. (1955). Manual of Biochemical Assays. Medgiz, Moscow.

Vojnar, A. O. (1953). Biological Function of Microelements in Animals and Man. Sovetskaja nauka, Moscow.

Vozár, L. (1959). Biologia (Bratislava), 14, 507.

Weber, E. (1964). Grundiss der biologischen Statistik, 5th ed. Fischer, Jena. 